\title{
THE EFFECTS OF THE CASH TRANSFER PROGRAMME FOR POOR STUDENTS ON CHILD'S WORK PARTICIPATION: Evidence from Java (Indonesia)
}

\author{
Achsanah Hidayatina \\ The Center for Political Studies, \\ Indonesian Institute of Sciences, Jakarta, Indonesia \\ Email: ahidayatina@gmail.com
}

\begin{abstract}
Cash transfer is considered as a relatively safe policy instrument to improve child welfare. Over the past ten years, Indonesia has made major progress in reducing the number of children involved in child work. It has done so primarily by expanding education provision to increase the time children spend in school and reduce the time children allocate to work. This progress has been supported by the implementation of poverty alleviation programmes that provided income assistance to vulnerable families. This paper aims to analyse whether cash transfer subsidies provided by the Government of Indonesia were sufficient for children to decrease the probability of working and reduce the hours of working activities of children within households. This paper includes a detailed exploration of differences in impacts by children's gender and areas of residence. This paper uses cross sectional data to analyse the effects of the programme on child's work. The data covers children aged from six to I4 from the Indonesian Family Life Survey (IFLS) in 20I4. The data is non-experimental and programme participation is not randomly assigned. The bivariate probit with endogenous dummy models are also estimated for the probability that a child is working, controlling for additional characteristics of the child, head of household, household and community-level characteristics. The results of this paper are particularly relevant for understanding the role of cash transfer programmes in developing countries. The findings of this paper suggest that the Government of Indonesia needs to reach the poorest children who are out of school.
\end{abstract}

Keywords: cash transfer, bivariate probit, IFLS, child work

\section{Abstrak}

Bantuan siswa miskin merupakan salah satu bantuan langsung dari Pemerintah Indonesia sebagai instrument kebijakan untuk meningkatkan kesejahteraan anak. Selama lebih dari Io tahun, Indonesia sudah banyak kemajuan dalam mengurangi jumlah anak bekerja. Hal ini merupakan dampak dari perluasan akses pendidikan untuk meningkatkan jumlah waktu anak di sekolah dan mengurangi jam anak untuk bekerja. Kemajuan tersebut didukung oleh implementasi kebijakan pengurangan kemiskinan yang memberikan dana bantuan untuk rumah tangga miskin. Tulisan ini bertujuan untuk menganalisis apakah program bantuan dari pemerintah Indonesia cukup untuk mengurangi kemungkinan anak bekerja dan mengurangi jam kerja mereka di dalam sebuah rumah tangga. Tulisan ini menganalisis lebih dalam dampak bantuan siswa miskin yang dibedakan dari jenis kelamin dan area tempat tinggal. Data yang digunakan bersumber dari IFLS Tahun 2014 meliputi anak usia 6-I4 tahun. Bivariate Probit dengan model endogenous dummy digunakan untuk mengestimasi kemungkinan seorang anak bekerja, dengan variabel karakteristik anak, kepala rumah tangga, rumah tangga dan komunitas. Hasil dari tulisan ini sangat relevan untuk memahami bagaimana bentuk kebijakan bantuan tunai di sebuah Negara berkembang. Hasil dari tulisan ini bahwa Pemerintah Indonesia perlu untuk memperluas penerima program kepada anak-anak yang putus sekolah. 


\section{INTRODUCTION}

In the last few decades, national efforts in alleviating poverty in the developing world have concentrated on human capital investment as a strategy for development. Cash transfer programmes are among the most common social protection policies which promote human capital investment. Moreover, several developing countries in Latin America and Asia have been implementing cash transfer and subsidies programmes to address challenges posed by poverty among poor households in general and that of children in particular. Examples of such programmes are Progresa in Mexico, Bolsa Familia in Brazil, Familias en Accion in Colombia, The Bono de Desarrollo Humano in Ecuador, and The Atencion a Crisis in Nicaragua. There is growing evidence that cash transfer programmes have been effective at raising human capital and contributing to poverty alleviation among poor households (Baez \& Camacho, 20ıг; Peruffo \& Ferreira, 20I7).

The issue of child's work has received considerable critical attention in developing countries. This is because poor households are especially vulnerable to economic shocks and can have difficulties in sustaining consumption. As a consequence, they might have to take children out of school to save on school fees and send children to work as an additional income source (de Janvry, Finan, Sadoulet, \& Vakis, 2006; Rosati, 2003). Examples of such working activities are working in home-based enterprises, family farm businesses, and substitute for parent's time by doing household chores. Social protection programmes such as cash transfers provide financial assistance to prevent the household from economic shocks and child work. By alleviating the economic vulnerability of households, social protection policies may remove some of the reasons why families send children to work (Rosati, 2003). The incidence of working children is always related to a decline in educational level and performance, which, in the long run, will reduce the quality of human capital.

Cash transfers related to education is one of the policy options that deal with the working child issue. With this policy, the government or other public agency provides cash to a household when a family has school-age children and meets certain requirements. The assumption behind this policy is that increasing school enrolment and attendance would lead to a decrease in participation of children in working activities within households and children can be more focused on school related activities (Hoop \& Rosati, 2014; Rosati, 2003; Tabatabai, 2009).

Indonesia has been implementing a wide range of policies and programmes to reduce poverty and encourage investment in human capital. The Government of Indonesia also implemented a cash transfer to poor students programme to protect enrolment in education and reduce child's work. Cash transfers for poor students, which began in 2008 , has now become the third-largest poverty alleviation programme in Indonesia, with more than in million beneficiary students in 2016 (Bappenas, 2013; Ministry of Finance, 2016b) . The lack of empirical studies addressing the effectiveness of cash transfers to poor students programme in Indonesia is an area worth exploring, specifically on how to adapt the cash transfer programme for different contexts related to children's issues.

\section{LITERATUR REVIEW}

\section{Poverty and Child Labour}

Child labour is a complex problem in developing countries particularly in Asia, Latin America and Africa. Government, policymakers and researchers have focused their attention on how to deal with these issues. The effectiveness of the intervention policies and programme implementations to deal with child work issues are based on adequate knowledge of the causes that drive children to work. There are several underlying factors that contribute to the existence of child work: for instance, poverty (Basu \& Van, I998), household characteristics (Amin, Shakil Quayes, \& Rives, 2004; Suryahadi, Priyambada, \& Sumarto, 2005), household income shocks (Bandara, Dehejia, \& Lavie-Rouse, 20I5; Beegle, Dehejia, \& Gatti, 2006), market imperfection (Baland \& Robinson, 2000; Dehejia \& Gatti, 2005) and parental illness (Alam, 2015). 
The theoretical literature on child labour has stressed the role of poverty as one of the main determinants of a parent's decision to send their children to work rather than study (Basu \& Van, I998; Deb \& Rosati, 2002). Research on poverty and child labour decisions has received considerable critical attention in the past few years. Most research has used household income or expenditure or consumption as the proxy for poverty. Basu and Van (I998) found that poverty is an important determinant of working children. According to the authors when household income increases, the need for a financial contribution by the children decreases and household are able to invest in their children's education. In addition, the authors noted that children living in poverty often have limited access to basic education and are involved in work activities.

\section{Cash Transfers and Child Labour}

Cash transfer programmes are expected to reduce the probability of child work activities and number of hours among school-age children through two possible channels. First, cash transfers reduce the cost of schooling which includes school supplies, textbooks, and uniform (Edmonds \& Schady, 20I2; Gee, 20I0; Hoop \& Rosati, 20I4). Second, conditional cash transfers require family beneficiaries to have their children regularly attend school, thus, the programme increases the time children spend in school and reduces the time to participate in work activities (Edmonds \& Schady, 2012; Gee, 20Io; Hoop \& Rosati, 20I4). On the other hand, the household uses part of the cash transfer to invest in assets such as in farming and small business that make child work more productive, thus more profitable (Rosati, 2003). In this situation, the cash transfer could increase the value of children's work to the household (Edmonds \& Schady, 2012; Hoop \& Rosati, 2014; Pais, Silva, \& Teixeira, 2017; Rosati, 2003). Because of this, the likely overall effect of cash transfer programmes on child labour is uncertain.

There is growing evidence that cash transfers are effective strategies for reducing child labour in developing countries (Attanasio et al., 20ıо; Del Carpio, Loayza, \& Wada, 20ı6;
Edmonds \& Schady, 20I2; Galiani \& McEwan, 2013; Maluccio \& Flores, 2005; Ravallion \& Wodon, 2000; Skoufias \& Parker, 200I). Most studies focused on children's participation in work, with a few studies discussing the impact on working hours. Some studies focused on specific activities such as work in agriculture, whereas others used a more general definition such as child work in economic activities or household chores. In addition, methods practised in previous studies are varied. Some studies used randomised experiments, and other studies implemented different methods, such as instrumental variable regression, difference-in-difference, propensity score matching, or linear parametric regression.

\section{Indonesian Cash Transfer Programme for Poor Students}

The cash transfer for poor students is a result of the level of commitment from the Government of Indonesia in providing equal access to basic education for the poor. This programme provides cash assistance for students aged six to 18 from poor and vulnerable households who are enrolled in primary, junior secondary, and senior high school from both public and private schools. Protection of vulnerable people, particularly children, is important because Indonesia enjoyed its demographic bonus ${ }^{3}$ and investing in children today will drive opportunities to generate capital and wealth (World Bank, 20I2a). The number of those aged Io -24 has increased significantly from 33.5 million in I97I to 65.6 million, or 25.7 per cent of the population in 2015 (BPS, 2015).

From 2008 to 2016 , the number of programme beneficiaries across different educational levels and regions continued to increase. In 2008, the cash transfer for poor students targeted around three million students across all levels of schooling and in 2016 the coverage was at II million students (see Figure 2). In 20I6, IDR II trillion or around US\$ 850 million was spent on the programme, equivalent to Io per cent of central government education expenditure. In

3 This demographic bonus refers to the potential of a larger proportion of working aged population and a lower dependency ratio, which can drive opportunities to generate capital and wealth (World Bank, 20I2a) 
2016, the coverage of the programme reached I9.2 million students at a budget of IDR I4 trillion and covered 34 provinces (Ministry of Finance, 20i6a).

Figure I. Indonesian Cash Transfer Programme for Poor Students Expenditure and Coverage 2008-2016



Source: Ministry of Finance (20I6b); World Bank (20I2b)

\section{METHODOLOGY}

\section{Data Source}

This paper uses data from wave five of the IFLS, which was fielded in late 2014 and early 2015. The IFLS survey contains detailed information on a wide range of individual and household characteristics, including the household socio-demographic structure, such as age and educational background as well as household size, household assets, household income and expenditure. In addition, the data at the community level collects information about the presence of education facilities, natural disaster and poverty alleviation programmes.

\section{Descriptive Statistics}

The sample of households is restricted to those who have children aged between six and I4 years old $^{4}$ in six provinces on Java Island namely, Jakarta, West Java, Central Java, Yogyakarta, East Java and Banten. The sample covers both urban and rural areas. Table I provides detailed information about the sample of children used in the analysis of this paper. The final analysis includes 4,5I2 children between six and I4 years old who live in 3,509 households with the number of male children slightly higher than female.

$4 \quad$ The age range is based on the official age of entry into primary school and the minimum age of children to enter the labour market is 15 years old. 
Table I. Sample of Households and Children across Beneficiaries and Non-Beneficiaries Cash Transfer for Poor Students Programme

\begin{tabular}{|c|c|c|c|c|c|c|}
\hline \multirow[t]{2}{*}{$\begin{array}{l}\text { Sample } \\
\text { N }\end{array}$} & \multicolumn{2}{|l|}{ Total } & \multicolumn{2}{|c|}{$\begin{array}{l}\text { Non-Benefi- } \\
\text { ciary } \\
\text { Group }\end{array}$} & \multicolumn{2}{|c|}{$\begin{array}{l}\text { Beneficiary } \\
\text { Group }\end{array}$} \\
\hline & $\%$ & $\mathbf{N}$ & $\%$ & $\mathbf{N}$ & $\%$ & \\
\hline $\begin{array}{l}\text { Number of } \\
\text { household }\end{array}$ & 3,509 & 100.00 & 2,815 & 80.22 & 694 & 19.78 \\
\hline $\begin{array}{l}\text { Number of } \\
\text { children }\end{array}$ & 4,512 & 100.00 & 3,543 & 78.52 & 969 & 21.48 \\
\hline \multicolumn{7}{|l|}{$\begin{array}{l}\text { Children } \\
\text { by gender }\end{array}$} \\
\hline Boys & 2,322 & 51.46 & 1,835 & 40.67 & 487 & 10.79 \\
\hline Girl & 2,190 & 48.54 & 1,708 & 37.85 & 482 & 10.68 \\
\hline \multicolumn{7}{|l|}{$\begin{array}{l}\text { Children } \\
\text { by resi- } \\
\text { dence }\end{array}$} \\
\hline Rural & 1,484 & 32.89 & 1,104 & 24.47 & 380 & 8.42 \\
\hline Urban & 3,028 & 67.11 & 2,439 & 54.06 & 589 & 13.05 \\
\hline
\end{tabular}

Source: Author's calculation from $\mathrm{IFLS}_{5}$ ( 6 provinces on Java island).

Child's work used in the empirical analysis was measured using the participation of children doing various activities and the number of hours worked per child in the last week as a robustness check. This paper considers children who are engaged in economic activities, children who are involved in household chores and children who participated in any activity as a definition of work. Economic activities are defined as activities that contribute to household income. This may include wage labour, but also non-wage labour such as working for a family farm business and a family non-farm business. Family farm business consists of agricultural activities and livestock productivity. Family non-farm business consists of unpaid activities at the shop. In most cases, children working for their families are unpaid labour for tending crops in the field, processing crops and tending livestock (Sim, Suryadarma, \& Suryahadi, 20I7). Household chores are defined as activities such as cleaning, cooking or washing, caring for siblings and collecting water. Considering household chores as well as economic activities is important when it comes to accurately assessing its potentially negative effect on a child's welfare (Del Carpio et al., 20I6; Miller \& Tsoka, 20I2; Zapata, Contreras, \& Kruger, 20II).
Table 2. The Participation and Average Hours of Child's Work by Activity, Gender and Residence

\begin{tabular}{|c|c|c|c|c|c|c|}
\hline \multirow[b]{2}{*}{$\begin{array}{l}\text { Gender of } \\
\text { Children / } \\
\text { Residence }\end{array}$} & \multicolumn{2}{|c|}{$\begin{array}{l}\text { Household } \\
\text { Chores }\end{array}$} & \multicolumn{2}{|c|}{$\begin{array}{l}\text { Economic Ac- } \\
\text { tivities }\end{array}$} & \multicolumn{2}{|c|}{$\begin{array}{l}\text { Any Activity } \\
\text { (Total Hours) }\end{array}$} \\
\hline & $\begin{array}{l}\text { Par- } \\
\text { ticipa- } \\
\text { tion } \\
\text { Rate } \\
\text { (\%) }\end{array}$ & $\begin{array}{l}\text { Aver- } \\
\text { age } \\
\text { hours/ } \\
\text { week }\end{array}$ & $\begin{array}{l}\text { Par- } \\
\text { ticipa- } \\
\text { tion } \\
\text { Rate } \\
\text { (\%) }\end{array}$ & $\begin{array}{l}\text { Aver- } \\
\text { age } \\
\text { hours/ } \\
\text { week }\end{array}$ & $\begin{array}{l}\text { Par- } \\
\text { ticipa- } \\
\text { tion } \\
\text { Rate } \\
(\%)\end{array}$ & $\begin{array}{l}\text { Aver- } \\
\text { age } \\
\text { hours/ } \\
\text { week }\end{array}$ \\
\hline Boys & 9.20 & 0.60 & 2.66 & 0.40 & 10.59 & 1.10 \\
\hline Girls & 15.89 & 1.44 & 2.30 & 0.46 & 16.53 & 1.90 \\
\hline Urban & 16.60 & 0.90 & 3.26 & 0.45 & 17.89 & 1.34 \\
\hline Rural & 8.49 & 1.22 & 1.71 & 0.40 & 9.24 & 1.62 \\
\hline Total & 25.09 & 1.00 & 4.96 & 0.43 & 27.13 & 1.43 \\
\hline
\end{tabular}

Note: Mean number of hours for the sample, includes those who report zero hours on each activity.

Source: Author's calculation from IFLS 5 (6 provinces on Java island).

Table 2 shows descriptive statistics with respect to household chores, economic activities and any activity of the sample of individuals. Additionally, Table 2 shows the participation rate and the average number of hours worked in the prior week on working activities by children by gender and residence. In this table, 27.I3 per cent of those children are involved in household chores, economic activities and any activity, while more children are engaged in household chores than economic activities. Boys are more likely to be involved in economic activities than girls: about 2.7 per cent and 2.3 per cent respectively. The prevalence of child's work shows that urban children have higher participation both in domestic and economic activities. Relatively, urban children are I7.89 per cent more likely than rural children to be involved in household chores, economic activities and both activities.

Table 2 also summarises the duration of work which is divided into three categories: (i) hours spent on household chores; (ii) hours spent on economic activities and (iii) total hours worked. The duration of work includes children in the activity who report zero working hours, thus clearly these children are not working. On average, children work I.43 hours each week, with I hour spent on household work and 0.43 hours on economic activity. Table 2 shows around 27 per cent of children aged six to I4 reported spending on average I.43 hours on total work hours. 
Table 3 summarises background characteristics of children and their families for the 4,512 children separately for beneficiary and non-beneficiary groups. Table 3 reveals a number of significant differences between beneficiary and non-beneficiary groups at the household levels. It can be clearly seen that the figures revealed some statistically significant differences at the child and head of household level between the beneficiary and non-beneficiary groups.

Table 3. Comparison of Independent Variables across Programme Participating and Programme Non-Participating Groups

\begin{tabular}{|c|c|c|c|c|}
\hline \multirow[b]{2}{*}{ Children age and sex } & \multirow[t]{2}{*}{$\begin{array}{l}\text { Non- } \\
\text { Benefi- } \\
\text { ciary }\end{array}$} & \multirow[t]{2}{*}{$\begin{array}{l}\text { Benefi- } \\
\text { ciary }\end{array}$} & \multicolumn{2}{|c|}{$\begin{array}{l}\text { Mean Differ- } \\
\text { ence }\end{array}$} \\
\hline & & & & \\
\hline Age & 9.7748 & 10.1569 & -0.3821 & $* * *$ \\
\hline Male & 0.5179 & 0.5026 & 0.0153 & \\
\hline \multicolumn{5}{|l|}{ Head of household } \\
\hline Age & 44.1942 & 44.8751 & -0.6809 & $*$ \\
\hline Male & 0.8589 & 0.8070 & 0.0518 & $* * *$ \\
\hline Education & 9.7863 & 7.9226 & 1.8637 & $* * *$ \\
\hline \multicolumn{5}{|l|}{$\begin{array}{l}\text { Household charac- } \\
\text { teristics }\end{array}$} \\
\hline Has electricity & 0.9966 & 0.9948 & 0.0018 & \\
\hline Has clean floor & 0.8115 & 0.6450 & 0.1665 & $* * *$ \\
\hline Has strong wall & 0.9102 & 0.8421 & 0.0681 & $* * *$ \\
\hline Has own house & 0.7508 & 0.7358 & 0.0150 & \\
\hline Household size & 4.6424 & 5.0072 & -0.3648 & $* * *$ \\
\hline Has television & 0.9650 & 0.9329 & 0.0321 & $* * *$ \\
\hline $\begin{array}{l}\text { Non-food ex- } \\
\text { penditure }\end{array}$ & 15.4760 & 14.9768 & 0.4993 & $* * *$ \\
\hline Has land farming & 0.2185 & 0.2115 & 0.0069 & \\
\hline Has poultry & 0.2120 & 0.2652 & -0.0533 & $* * *$ \\
\hline \multicolumn{5}{|l|}{ Residence } \\
\hline Rural & 0.3116 & 0.3922 & -0.0806 & $* * *$ \\
\hline \multicolumn{5}{|l|}{$\begin{array}{l}\text { Community-level } \\
\text { characteristics }\end{array}$} \\
\hline $\begin{array}{l}\text { Number of flood } \\
\text { incidents }\end{array}$ & 1.0260 & 0.8947 & 0.1312 & \\
\hline $\begin{array}{l}\text { Has factory in } \\
\text { sub-districts }\end{array}$ & 0.6514 & 0.6863 & -0.0348 & $* *$ \\
\hline $\begin{array}{l}\text { Number of el- } \\
\text { ementary school }\end{array}$ & 7.0587 & 6.4045 & 0.6542 & $* * *$ \\
\hline $\begin{array}{l}\text { Number of ju- } \\
\text { nior high school }\end{array}$ & 4.6314 & 4.5150 & 0.1164 & \\
\hline $\begin{array}{l}\text { Level of poverty } \\
\text { programme }\end{array}$ & 0.6361 & 0.6466 & -0.0104 & $* *$ \\
\hline
\end{tabular}

Note: All estimates are based on households with children aged six to fourteen.

Source: Author's calculation from IFLS 5 ( 6 provinces on Java Island). $* * * p<0.0 \mathrm{I},{ }^{* *} p<0.05,{ }^{*} p<0 . \mathrm{I}$

\section{DEFINITION OF VARIABLES}

\section{The Dependent Variables}

The first outcome is used to examine whether the cash transfer programme has an impact on the involvement of the child in different working activities. The first outcome measured in this paper is labelled as chwork, a dummy variable that takes the value of one if a child is participating in household chores, economic activities, as well as any activity, and a value of zero otherwise. The estimated value of chwork is the probability that a child will engage in any of those activities. A negative relationship is expected between the probability of participating in the programme and child's work (Miller \& Tsoka, 20I2; Skoufias \& Parker, 200I). That is, a cash transfer is expected to decrease the probability of child work.

The second outcome is used for the robustness check as to whether the cash transfer programme has any impact on the duration of child's work. The second outcome uses working hours for measurement, which is labelled as hourswork. This variable is a count variable that records the total hours spent working in economic activities and household chores in the previous week. A negative relationship is expected between participating in the programme and the number of hours of child work (Del Carpio et al., 20I6; Edmonds \& Schady, 20I2; Pais et al., 20I7). That is a cash transfer is expected to reduce the child's work hours.

\section{The Independent Variables}

The main independent variable is labeled as cashtrans; this variable takes on a value of one if a child received a cash transfer and a value of zero otherwise. The transfer appears to have reduced the participation of child's work and number of working hours for household chores and economic activities (Del Carpio et al., 20I6; Edmonds \& Schady, 20I2; Miller \& Tsoka, 20I2; Skoufias \& Parker, 200I). As reported in Table 4, approximately $2 \mathrm{I} .48$ per cent of the children in the sample are participating in the programme, while the other 78.52 per cent are not. The participation in the cash transfer programme is potentially endogenous since unmeasured 
characteristics may affect both the likelihood of receiving transfer and the outcome variable of interest or child's work. Our empirical approach relies on cash transfer, and while we do observe whether or not an individual has received a cash transfer, we recognise that cash transfer variable is endogenous.

The endogeneity of this variable raises concerns because the recipients of the cash transfer programme were not assigned randomly; instead, students from poor households were specifically targeted. In other words, not every household is eligible for the programme. The targeting and selection of beneficiaries have been carried out by the central government using a unified database that contains lists of potential beneficiaries of cash transfer programme based on welfare level and socio-economic status of households. The eligibility criteria may induce different sources of selection bias including observable and unobservable factors that could be correlated with programme eligibility and work outcomes.
The child work issue is related to the characteristics of the individual children themselves, as well as the characteristics of their families and the communities where they live (De Silva \& Sumarto, 2015; Del Carpio et al., 20I6; Gee, 20I0; Miller \& Tsoka, 20I2; Suryahadi et al., 2005). To identify the factors that are associated with working activities of children within households, this section explores these characteristics. Guided by findings from previous studies, the characteristics consider those of the children themselves as well as those of the household heads, the households and the communities. These additional control variables are those that influence the household and these factors may also play a role in the effect of the cash transfer programme on child's work. In addition, the additional covariates in the model would help improve the precision of the estimates of the causal effect of interest.

Table 4. Variable Definitions and Descriptive Statistics

\begin{tabular}{|c|c|c|c|c|c|c|c|}
\hline \multirow{2}{*}{ Variable (s) } & \multirow{2}{*}{$\begin{array}{l}\text { Definition } \\
\text { Mean }\end{array}$} & \multicolumn{2}{|c|}{ Full Sample } & \multicolumn{2}{|c|}{$\begin{array}{l}\text { Non-Beneficiary } \\
\text { Group }\end{array}$} & \multicolumn{2}{|c|}{$\begin{array}{l}\text { Beneficiary } \\
\text { Group }\end{array}$} \\
\hline & & Mean & $\begin{array}{l}\text { Std. } \\
\text { Dev }\end{array}$ & Mean & $\begin{array}{l}\text { Std. } \\
\text { Dev }\end{array}$ & Mean & $\begin{array}{l}\text { Std. } \\
\text { Dev }\end{array}$ \\
\hline \multicolumn{8}{|c|}{ Dependent Variable } \\
\hline Hhwork & 1 if child works in household chores; 0 otherwise & 0.25 & 0.43 & 0.24 & 0.43 & 0.29 & 0.45 \\
\hline Ecwork & 1 if child works in economic activities; 0 otherwise & 0.05 & 0.22 & 0.04 & 0.20 & 0.07 & 0.26 \\
\hline Allwork & 1 if child works in any activity; 0 otherwise & 0.27 & 0.45 & 0.26 & 0.44 & 0.32 & 0.44 \\
\hline Hhhours & Number of hours in household chores/week & 1.00 & 3.09 & 0.95 & 3.09 & 1.20 & 3.08 \\
\hline Echours & Number of hours in economic activity/week & 0.43 & 3.22 & 0.36 & 2.83 & 0.70 & 4.33 \\
\hline Allhours & Number of hours in any activity/week & 1.43 & 4.62 & 1.31 & 4.36 & 1.88 & 5.43 \\
\hline \multicolumn{8}{|c|}{ Independent Variable } \\
\hline Cashtran & 1 if children received cash transfer; 0 otherwise & 0.21 & 0.41 & & & & \\
\hline \multicolumn{8}{|c|}{ Children Characteristics } \\
\hline Age & Child's age in years & 9.87 & 2.57 & 9.77 & 2.61 & 10.12 & 2.37 \\
\hline Sex & 1 if boy; 0 otherwise & 0.51 & 0.50 & 0.52 & 0.50 & 0.50 & 0.50 \\
\hline \multicolumn{8}{|c|}{ Head of HH Characteristics } \\
\hline Headage & Head of household's age in years & 44.34 & 10.53 & 44.19 & 10.74 & 44.88 & 9.71 \\
\hline Headsex & 1 if head of household is male; 0 otherwise & 0.85 & 0.34 & 0.86 & 0.35 & 0.81 & 0.39 \\
\hline Headeduc & Head of household's education in years & 9.39 & 3.84 & 9.79 & 3.91 & 7.92 & 3.17 \\
\hline Household Ch & eristics & & & & & & \\
\hline
\end{tabular}




\begin{tabular}{|c|c|c|c|c|c|c|c|}
\hline \multirow{2}{*}{ Variable (s) } & \multirow{2}{*}{$\begin{array}{l}\text { Definition } \\
\text { Mean }\end{array}$} & \multicolumn{2}{|c|}{ Full Sample } & \multicolumn{2}{|c|}{$\begin{array}{l}\text { Non-Beneficiary } \\
\text { Group }\end{array}$} & \multicolumn{2}{|c|}{$\begin{array}{l}\text { Beneficiary } \\
\text { Group }\end{array}$} \\
\hline & & Mean & $\begin{array}{l}\text { Std. } \\
\text { Dev }\end{array}$ & Mean & $\begin{array}{l}\text { Std. } \\
\text { Dev }\end{array}$ & Mean & $\begin{array}{l}\text { Std. } \\
\text { Dev }\end{array}$ \\
\hline Floor & $\begin{array}{l}1 \text { if the material is ceramic/marble/granite/terrazzo; } \\
0 \text { is cement/bricks/bamboo/dirt }\end{array}$ & 0.77 & 0.42 & 0.81 & 0.39 & 0.64 & 0.48 \\
\hline Wall & $\begin{array}{l}1 \text { if the material is cement/concrete/bricks; } 0 \text { is } \\
\text { wood/bamboo }\end{array}$ & 0.89 & 0.31 & 0.91 & 0.29 & 0.84 & 0.36 \\
\hline $\begin{array}{l}\text { Household } \\
\text { size }\end{array}$ & Number of the people in the household & 4.72 & 1.68 & 4.64 & 1.62 & 5.01 & 1.85 \\
\hline Television & 1 if household has television; 0 otherwise & 0.96 & 0.20 & 0.97 & 0.18 & 0.93 & 0.25 \\
\hline Poultry & 1 if household has poultry; 0 otherwise & 0.22 & 0.42 & 0.21 & 0.41 & 0.26 & 0.44 \\
\hline $\begin{array}{l}\text { Non-Food } \\
\text { Expendi- } \\
\text { ture }\end{array}$ & Natural log of non-food expenditure & 15.37 & 1.14 & 15.48 & 1.14 & 14.50 & 1.04 \\
\hline Rural & 1 if household lives in rural; 0 otherwise & 0.33 & 0.47 & 0.31 & 0.46 & 0.39 & 0.49 \\
\hline \multicolumn{8}{|c|}{ Community Characteristics } \\
\hline Factory & $\begin{array}{l}1 \text { if community has factory in sub-districts; } 0 \text { other- } \\
\text { wise }\end{array}$ & 0.66 & 0.47 & 0.65 & 0.48 & 0.69 & 0.46 \\
\hline Elementary & Number of elementary school & 6.92 & 5.97 & 7.06 & 6.05 & 6.40 & 5.65 \\
\hline Poverty & Level of poverty programme & 0.64 & 0.13 & 0.64 & 0.13 & 0.65 & 0.13 \\
\hline $\mathrm{N}$ & & 4,512 & & 3,543 & & 969 & \\
\hline
\end{tabular}

Note: The table presents means and standard deviations. All estimates are based on households with children aged six to fourteen. Mean number of hours for the sample includes those that report zero hours on each activity.

\section{Econometric Methods: The Bivariate Probit Model with Endogenous Dummy}

This paper evaluated the effect of cash transfer programme on child work by analysing the probability of participation in a particular type of activity of children within a bivariate Probit framework. The model estimated is a limited-dependent-variable model, where the dependent variable is binary; either the child is engaged in any of the different working activities or the child is not engaged in any activity. Meanwhile, the main independent variable is also binary; one if the children received a cash transfer and zero otherwise. In addition, the control variables are a set of children, household head, household and community-level characteristics. Thus, this paper considers how to estimate the effect of endogenous binary variables in a binary response model.
The bivariate Probit model is frequently used for estimating the effect of an endogenous binary regressor (Angrist, 200I; Gitto, Santoro, \& Sobbrio, 2006; Latif, 2009; Macdonald \& Shields, 2004). To account for endogeneity of the cash transfer programme in the child performing household chores, economic activities and any activity, the paper uses a recursive bivariate Probit model. The bivariate Probit model provides a convenient setting for estimating the effect of an endogenous binary regressor on a binary outcome variable in different activities, denoted, which are economic, household chores and any activity. The standard model assumes a constant treatment effect, the presence of exclusion restriction and the absence of simultaneity (Greene, 20I2). Formally, the structural model consists of two Probit equations: 
$W_{i j}=\alpha_{1}+X_{i} \beta_{1}+C T_{i j} \delta+\varepsilon_{1 i}$

$C T_{i j}^{G}=\alpha_{2}+X_{i} \beta_{2}+Z_{i j} \gamma+\varepsilon_{2 i}$

$W_{i j}=1 i f W_{i j}>0, C T_{i j}=1$ if $C T_{i j}>0$

Where:

$W_{i j}=1$ if a child $i$ is participating in activity $j$ and a value of zero otherwise.

$C T_{i j}=1$ if a child $i$ in activity $j$ received a cash transfer programme and a value of zero otherwise.

$W_{i j}$ and $C T_{i j}^{\mathrm{G}}$ are unobserved latent variables that determine whether a child is engaged in different activities and being a beneficiary of a cash transfer for poor students respectively.

$\beta_{1}, \beta_{2}, \delta$ and $\gamma$ are the unknown parameters of interest that we wish to estimate and $\varepsilon_{1}, \varepsilon_{2}$ are the error terms.

$X_{i}$ is a vector of exogenous observable characteristics for children $i$, which are assumed to be predetermined to participate in different activities and the cash transfer programme.

$Z_{i}$ is a vector of identifying restrictions that are assumed to influence the probability of beneficiary a cash transfer programme, but are orthogonal to $\varepsilon_{1 i}$, and $E\left[\varepsilon_{1}\right]=E\left[\varepsilon_{2}\right]=$ $0, \quad \operatorname{var}\left[\varepsilon_{1}\right]=\operatorname{var}\left[\varepsilon_{2}\right]=1$ with $\operatorname{cov}\left[\varepsilon_{1} \varepsilon_{2}\right]=\rho$.

Finally, is the correlation between and, which is assumed to follow a bivariate normal distribution (Wooldridge, 20Io). The likelihood ratio test is used to determine whether is significantly different from zero. If, are not independent due to endogeneity of cash transfer for poor students, then maximum likelihood estimation of equation (I) using a univariate Probit model will not provide consistent estimates of the impact of programme on child work. However, when and are not independent, estimating child's work and cash transfer programme jointly in a recursive bivariate Probit framework will yield consistent estimates. In addition, we run bivariate Probit regressions and clustering standard errors at the community level because some children in our sample are in the same households and some households will also have the same communitylevel characteristics. Because of this, standard errors of the coefficients have been corrected for clustering at the community level.

\section{Robustness Check}

In order to check the robustness of our results, we provide evidence based on two different identification strategies. First, we provide evidence on two dimensions of heterogeneity of impact based on gender and residence using data on children participation in different types of activity. Second, we provide evidence of the effect of the cash transfer programme using data on the number of hours worked.

\section{RESULTS AND DISCUSSIONS}

\section{Empirical Results: Bivariate Probit Model with Endogenous Dummy}

The marginal effects of the explanatory variables are reported since these effects cannot be inferred directly from the regression coefficients. In addition, the average marginal effects in Table 5 are calculated as the change of the effect of the treatment on the treated, or the expected effect of the treatment on individuals with observed characteristic who participated in the programme.

\section{Estimates of Marginal Effects}

Table 5 presents average marginal effects of all explanatory variables on the probability that beneficiary children are engaged in different activities. The results drawn from Table 5 is that the cash transfer programme implemented in six 
provinces on Java Island had the overall impact of reducing the probability of work activities of children within households. There is a statistically significant decrease or significant impact on the probability of engaging in household chores. For a child receiving a cash transfer, the probability of doing chores is lower by about 34 percentage points. In addition, it is evident from the results that the cash transfer programme given to children was enough to decrease the probability of a child working in economic activities by 38 percentage points. The effect of the programme on participation in economic activities is slightly larger than in household chores. The results also show a significant effect of the programme on participation in any form of working activities of children within households. Children in the programme are 32 percentage points less likely to perform any activity within households. The present findings seem to be consistent with other research in Mexico (Skoufias \& Parker, 200I), Nicaragua (Maluccio \& Flores, 2005), Ecuador (Edmonds \& Schady, 20I2) and Honduras (Galiani \& McEwan, 2013). On the other hand, these results differ from Colombia CCTs in the 20 Io estimate of impact of cash transfer that participation in income-generating work remained largely unaffected (Attanasio et al., 20Io).

For household chores, other coefficients, such as the children's age and gender, education of the head of households, household size, and household non-food expenditure, jointly determine the probability of participants of cash transfer programme and engagement in household chores. The marginal effect of children's age on the probability of engaging in household chores is 0.0204; this means that a one-year increase in age will add about 2 percentage points to the probability that a child will be involved in household chores. The marginal effect of the dummy variable for a male child is -0.09I4, meaning that, on average, a boy's probability of being engaged in household chores is 9 percentage points lower than girls. The marginal effect of parental education is -0.0063; this means that having more years of education for household heads lowers the probability of children being involved in household chores; each additional year of education of household heads decreases the probability by about 0.6 percentage points.

Table 5 also shows that the reduction in the probability of a child's work does not depend on the gender and age of the head of the household. Household size is negative and statistically less significant on probability of involvement in household chores. The probability that a child will engage in household chores decreases by I percentage point for a one-person increase in family size. Children with more siblings might be less engaged in household chores. In other words, more siblings might also mean more helping hands, which allows for a division of tasks at home (Webbink, Smits, \& de Jong, 2013). The marginal effect of household non-food expenditure is -0.0178, which means that each additional I per cent increase in non-food expenditure reduces the probability of engaging in household chores by 0.02 percentage points.

Table 5. Marginal Effect after Bivariate Probit Estimation

\begin{tabular}{|c|c|c|c|c|c|c|c|c|c|}
\hline \multirow{4}{*}{$\begin{array}{l}\text { Independent } \\
\text { Variables } \\
\text { Cash Transfer }\end{array}$} & \multicolumn{9}{|c|}{ Dependent Variable(s) } \\
\hline & \multicolumn{3}{|c|}{ Household Chores } & \multicolumn{3}{|c|}{ Economic Activities } & \multicolumn{3}{|c|}{ Any Activity } \\
\hline & \multicolumn{2}{|c|}{$\begin{array}{l}\text { Average Marginal } \\
\text { Effect }\end{array}$} & \multirow{2}{*}{$\begin{array}{l}\begin{array}{l}\text { Std. } \\
\text { error }\end{array} \\
0.0980\end{array}$} & \multicolumn{2}{|c|}{$\begin{array}{l}\text { Average Marginal } \\
\text { Effect }\end{array}$} & \multirow{2}{*}{$\begin{array}{l}\begin{array}{l}\text { Std. } \\
\text { error }\end{array} \\
0.1453\end{array}$} & \multicolumn{2}{|c|}{$\begin{array}{l}\text { Average Mar- } \\
\text { ginal Effect }\end{array}$} & \multirow{2}{*}{$\begin{array}{l}\begin{array}{l}\text { Std. } \\
\text { error }\end{array} \\
0.1496\end{array}$} \\
\hline & -0.3388 & $* * *$ & & -0.3779 & $* * *$ & & -0.3219 & $* *$ & \\
\hline Children Age & 0.0204 & $* *$ & 0.0099 & 0.0390 & $* * *$ & 0.0057 & 0.0214 & & 0.0166 \\
\hline Children Sex & -0.0914 & $*$ & 0.0503 & 0.0117 & & 0.0208 & -0.0760 & & 0.0645 \\
\hline Head HH Sex & 0.0225 & & 0.0163 & 0.0793 & $* * *$ & 0.0312 & 0.0327 & & 0.0261 \\
\hline Head HH Age & 0.0009 & & 0.0006 & -0.0018 & $*$ & 0.0011 & 0.0006 & & 0.0005 \\
\hline Head HH Educ & -0.0063 & $*$ & 0.0035 & -0.0056 & & 0.0039 & 0.0047 & & 0.0039 \\
\hline HH Floor & -0.0067 & & 0.0121 & -0.0018 & & 0.0254 & -0.0094 & & 0.0140 \\
\hline
\end{tabular}




\begin{tabular}{llllllll}
\hline \multirow{2}{*}{$\begin{array}{l}\text { Independent } \\
\text { Variables }\end{array}$} & \multicolumn{7}{l}{ Dependent Variable(s) } \\
\cline { 2 - 8 } & \multicolumn{2}{l}{ Household Chores } & \multicolumn{2}{l}{ Economic Activities } & \multicolumn{2}{l}{ Any Activity } \\
\cline { 2 - 8 } & $\begin{array}{l}\text { Average Marginal } \\
\text { Effect }\end{array}$ & $\begin{array}{l}\text { Std. } \\
\text { error }\end{array}$ & $\begin{array}{l}\text { Average Marginal } \\
\text { Effect }\end{array}$ & $\begin{array}{l}\text { Std. } \\
\text { error }\end{array}$ & $\begin{array}{l}\text { Average Mar- } \\
\text { ginal Effect }\end{array}$ & $\begin{array}{l}\text { Std. } \\
\text { error }\end{array}$ \\
\hline HH Wall & 0.0281 & 0.0236 & -0.0399 & 0.0363 & 0.0244 & 0.0279 \\
\hline HH Size & -0.0141 & $*$ & 0.0077 & 0.0028 & 0.0065 & -0.0126 & 0.0101 \\
\hline HH Television & 0.0067 & 0.0218 & -0.0716 & 0.0581 & 0.0006 & 0.0206 \\
\hline HH Poultry & 0.0064 & 0.0117 & 0.0089 & 0.0253 & 0.0057 & 0.0118 \\
\hline HH Non-Food Exp & -0.0178 & $* *$ & 0.0087 & 0.0121 & 0.0119 & 0.0172 & 0.0130 \\
\hline Rural & -0.0014 & 0.0146 & -0.0506 & $* *$ & 0.0241 & -0.0057 & 0.0143 \\
\hline Comm Factory & -0.0124 & 0.0152 & -0.0636 & $* * *$ & 0.0243 & -0.0151 & 0.0189 \\
\hline Comm Primary School & -0.0012 & 0.0011 & -0.0064 & $* * *$ & 0.0022 & -0.0015 & 0.0014 \\
\hline Comm Poverty Prog & -0.0643 & 0.0544 & 0.1240 & 0.0970 & -0.0584 & 0.0694 \\
\hline
\end{tabular}

Note: Robust standard errors are corrected for clustering at the communities' level.

$* * * p<0.01, * * p<0.05, * p<0.1$

Source: Author's calculation from IFLS 5 (6 provinces on Java island).

For economic activities, the result of particular interest is the positive sign on the coefficient for children's age. The older the child, the greater the probability the child works; each additional year adds 4 percentage points to the probability of working in economic activities. In addition, there are also different impacts based on whether or not the child is living with a male head of household and/or an older head of household. Having a male head of household decreases the probability of a child working in income activities by 8 percentage points. The older the male head of household is, the greater the decrease in the probability of the child working. The marginal effect of the rural variable is -0.0506; this means that living in a rural area decreases the probability of a child working in economic activities by 5 percentage points.

In terms of community characteristics, the presence of an additional factory and primary school decreases the probability of a working child. The number of primary schools in the sub-district significantly decreases the probability of child working in economic activities by 0.6 percentage point for a one-primary school increase in the sub-districts. A possible explanation for these results may be the lack of adequate primary schools, especially in rural

areas. These results indicate that increased infrastructure of school buildings will increase household demand for schooling, raise the enrolment rate and thereby decrease the probability of children working. Furthermore, the availability of primary schools also decreases the distance of the children to get to the school to receive education.

This finding has important implications for developing countries that increase the number of schools, particularly in rural areas, and the introduction of social programmes, such as income transfer to poor students, with the condition that the child should enrol and attend school. This can also explain changes in children's participation in economic activities. In addition, the presence of a factory in the sub-district also significantly decreases the probability of child working by 6 percentage points for a one-factory increase in the sub-districts. This result may be explained by the fact that a new factory in a sub-district creates a high demand for skilled labour, thus reducing child work. Also, because members of households have better employment prospects, so income is supplemented. For the outcome of any activity, there are no other explanatory variables that have a significant impact on determining whether participation in the cash 
transfer programme affects working activities of children.

\section{Robustness Checks Based on Gender and Residence}

In order to investigate the robustness of the results, this paper estimated separate bivariate Probit models based on gender: boys and girls, and residence: urban and rural. Table 6 shows the marginal effects of the cash transfer to poor students on participation in different activities based on gender and residence to test for heterogeneous effects of the programme. The main results show that the programme has different impacts on children with different observable characteristics. From the analysis based on gender, the estimates show that boys who have benefitted from the cash transfer programme experienced a negative statistically significant impact on the probability of engaging in all activities compared to girls. Further, the estimates also show that girls experienced a negative impact of the cash transfer programme

Table 6. The Effects of Cash Transfer by Child Attributes only on household chores. Cash transfer programmes seem to reduce the pressure for girls to work in household chores by around 34 percentage points, but the greatest improvements were among boys. The effects of the programme are generally largest for boys whose participation in household chores decreased by around 40 percentage points. The results are strongly significant in statistical terms at the one and five per cent levels respectively. The analysis by gender uncovers clear differences in the magnitude of effects of the cash transfer programme for working participation of boys and girls. A possible explanation for this might be the common findings in rural areas where girls traditionally lag behind boys for school enrolment. An incentive programme like Progresa in Mexico, provided larger transfers or stronger incentives to households with girls as a strategy to reduce the sex gap in school enrolment and substitute schooling for work (Skoufias \& Parker, 200I).

\begin{tabular}{|c|c|c|c|c|c|c|c|c|c|}
\hline \multirow{3}{*}{$\begin{array}{l}\text { Sub-Sam- } \\
\text { ples }\end{array}$} & \multicolumn{9}{|c|}{ Dependent Variable(s) } \\
\hline & \multicolumn{3}{|c|}{ Household Chores } & \multicolumn{3}{|c|}{ Economic Activities } & \multicolumn{3}{|c|}{ Any Activity } \\
\hline & \multicolumn{2}{|c|}{$\begin{array}{l}\text { Average Marginal } \\
\text { Effect }\end{array}$} & \multirow{2}{*}{$\begin{array}{l}\text { Std.error } \\
0.1003\end{array}$} & \multicolumn{2}{|c|}{$\begin{array}{l}\text { Average Marginal } \\
\text { Effect }\end{array}$} & \multirow{2}{*}{$\begin{array}{l}\text { Std.error } \\
0.1804\end{array}$} & \multicolumn{2}{|c|}{$\begin{array}{l}\text { Average Marginal } \\
\text { Effect }\end{array}$} & \multirow{2}{*}{$\begin{array}{l}\text { Std.error } \\
0.1347\end{array}$} \\
\hline Boys & -0.3990 & $* * *$ & & -0.4436 & $* *$ & & -0.3335 & $* *$ & \\
\hline Girls & -0.3446 & $* * *$ & 0.0157 & -0.3430 & & 0.2665 & -0.2818 & & 0.5990 \\
\hline Rural & -0.4174 & $* * *$ & 0.0527 & -0.3343 & & 0.5685 & -0.4003 & $* * *$ & 0.0865 \\
\hline Urban & -0.2652 & $* *$ & 0.1325 & -0.3065 & $* *$ & 0.1442 & -0.2889 & & 0.4745 \\
\hline
\end{tabular}

Note: Robust standard errors are corrected for clustering at the communities' level. Each of these comparisons is based on a regression

with a main effect, for example, a main effect for girls. Additional regressors included but not reported.

$* * * p<0.01, * * p<0.05, * p<0.1$

Source: Author's calculation from IFLS 5 (6 provinces on Java island).

For economic activities, the effects of the programme were generally larger for boys, whose participation in economic activities decreased by around 44 percentage points, but girls' participation in economic activities remained largely unaffected. The reason for this may be partly because of the lower sample size of girls, therefore resulting in a decrease in precision. In addition, programme participation is significantly associated with a decrease of 33 percentage points in the probability of working in any activities for boys who were aged six to I4 during the 20I4/2015 school year. These findings support other previous research that boys experience particular decreases in economic activities, whereas girls experience such decreases in household chores (Galiani \& McEwan, 2013; Miller \& Tsoka, 20I2; Skoufias \& Parker, 200I). These results agree with the findings of other studies in which programme impact of cash transfer may differ between girls and boys because of gender difference in types of 
working activity, opportunity costs of schooling and returns to education.

The fact that the cash transfer has a negative effect on child work for boys and girls shows that household decision on time allocation is partly driven by income effects. However, it seems that the magnitude of the effect is larger for boys than for girls on household chores. One possible reason is that, although the participation of boys in chores and economic activities are mainly due to income constraints and can be alleviated by cash transfer, the participation of girls in chores may be due to cultural norms ${ }^{5}$ and income transfer will have a smaller effect in the case of the latter. Comparing with the other cash transfer programmes such as Progresa in Mexico, this programme has relatively larger declines in the probability of child work for girls because the programme adjusted the subsidy amount and differentiated by gender. In other words, girls received higher amounts of subsidy.

To further analyse residence differences, this paper estimated disaggregated regressions using data for rural and urban areas, shown in Table 6. The distribution of impacts on the probability of child work varies with the location of programme beneficiaries as well. It can be clearly seen that the cash transfer programme has demonstrated a negative effect on the probability of children participating in household chores both in the rural and urban areas. The programme decreased the probability of children participating in household chores in both urban and rural by 27 and 42 percentage points respectively. The greatest reduction in household chores is for children in rural areas, by 42 percentage points. This paper also found a negative significant effect on economic activities in urban areas, by 3I percentage points. One possible explanation of this is because economic activities has a higher prevalence in urban areas because of labour market supply and higher opportunity in urban areas. Meanwhile, there is no significant effect for children participating in economic activities in rural areas. It shows that participation of children in economic 5 Previous studies show that in most developing countries girls are more likely than boys to do chores with the perception that it will teach them special skills and prepare them for adult life (Webbink et al., 20I3; Zapata et al., 20II). activities responds less to the programme in rural than in urban areas. However, the results show significant effects of the programme on participation in any form of child work in rural areas. Children in the programme who are living in a rural area are 40 percentage points less likely to be involved any activity within households.

\section{Robustness Checks Based on Work Hours}

A third phase of the analysis explores the robustness of the estimates of programme effects on number of work hours. The dependent variable in this paper is the number of hours children are involved in household chores, economic activities, and any activity or total hours after the programme had been implemented. In addition, the number of hours worked is non-negative and it is a count variable, thus we also fitted a Poisson regression. In this case, the count variable for the number of hours will include zero ${ }^{6}$ for children who do not work.

Table 6 shows the impact of the cash transfer programme on weekly hours worked. This model allows for unobserved heterogeneity and endogeneity in the covariates using the endogenous Poisson regression model. The final endogenous Poisson shows statistically significant rho parameters, which supports the adequacy of the endogenous Poisson specification. It is evident from the results in Table 6 that the cash transfer programme given to children was effective at reducing the amount of time spent in household chores, economic activities and any activity, thus allowing children to spend more time on school-related activities. The Wald test is highly significant, indicating a good model fit and we can reject the null hypopaper of no correlation between the treatment errors and the outcome errors. The effect of cash transfer on number of hours turns out to be statistically significant and negative, as in the bivariate Probit model. The results are indeed consistent with previous research which has shown that transfer programmes reduced hours worked (Attanasio et al., 20io; Del Carpio et al., 20I6; Edmonds \& Schady, 2012; Maluccio \& Flores, 2005). Although, this finding is different

6 There are more zeros in the data. The motivation for this robustness check is to handle the endogeneity of the cash transfer, not to handle the excess of zeros. 
from Bolsa Familia in Brazil, for children who are currently working, as their weekly working hours do not necessarily decrease (Pais et al., 20I7).

Table 7. Parameter Estimates Obtained with Endogenous Poisson-Quasi Maximum Likelihood

\begin{tabular}{|c|c|c|c|c|c|c|c|c|c|}
\hline \multirow{4}{*}{$\begin{array}{l}\text { Independent Variables } \\
\text { Cash Transfer }\end{array}$} & \multicolumn{9}{|c|}{ Dependent Variable(s) (Number of Hours) } \\
\hline & \multicolumn{3}{|c|}{ Household Chores (1) } & \multicolumn{3}{|c|}{ Economic Activities (2) } & \multicolumn{3}{|c|}{ Total Hours (3) } \\
\hline & \multicolumn{2}{|c|}{ Coefficient } & \multirow{2}{*}{$\begin{array}{l}\text { Std.error } \\
0.2385\end{array}$} & \multicolumn{2}{|c|}{ Coefficient } & \multirow{2}{*}{$\begin{array}{l}\text { Std.error } \\
0.1584\end{array}$} & \multicolumn{2}{|c|}{ Coefficient } & \multirow{2}{*}{$\begin{array}{l}\text { Std.error } \\
0.0769\end{array}$} \\
\hline & -0.8768 & $* * *$ & & -1.9424 & $* * *$ & & -0.5374 & $* * *$ & \\
\hline Children Age & 0.2925 & $* * *$ & 0.0254 & 0.4751 & $* * *$ & 0.0235 & 0.3270 & $* * *$ & 0.0151 \\
\hline Children Sex & -1.1906 & $* * *$ & 0.1651 & -2.2637 & $* * *$ & 0.1255 & -0.9035 & $* * *$ & 0.0667 \\
\hline Head HH Sex & -0.0296 & & 0.2937 & -0.1657 & & 0.1465 & 0.3744 & $* * *$ & 0.0891 \\
\hline Head HH Age & -0.0037 & & 0.0097 & -0.0401 & $* * *$ & 0.0042 & -0.0110 & $* * *$ & 0.0032 \\
\hline Head HH Education & -0.0033 & & 0.0182 & -0.0731 & $* * *$ & 0.0156 & -0.0258 & $* *$ & 0.0102 \\
\hline HH Floor & -0.6884 & $* *$ & 0.3097 & -0.1818 & & 0.1278 & -0.7837 & $* * *$ & 0.0874 \\
\hline HH Wall & 0.2513 & & 0.3207 & -0.7599 & $* * *$ & 0.1712 & 0.0735 & & 0.0996 \\
\hline HH Size & -0.1009 & & 0.0882 & -0.1197 & $* * *$ & 0.0206 & 0.0496 & $* *$ & 0.0189 \\
\hline HH Television & -0.0040 & & 0.4089 & -0.8565 & $* * *$ & 0.1597 & 1.8666 & $* * *$ & 0.1300 \\
\hline HH Poultry & 0.1948 & & 0.1035 & 0.5889 & & 0.1755 & 0.2276 & $* * *$ & 0.0785 \\
\hline HH Non-Food Exp & -0.0372 & & 0.1292 & 0.0064 & & 0.0834 & 0.0579 & $* *$ & 0.0292 \\
\hline Rural & -0.3083 & & 0.2889 & -0.0573 & & 0.1171 & -0.5539 & & 0.0872 \\
\hline Comm Factory & -0.0430 & & 0.3679 & 0.0821 & & 0.0971 & -0.2578 & $* * *$ & 0.0656 \\
\hline Comm Primary School & -0.0202 & & 0.0196 & -0.0242 & $*$ & 0.0095 & -0.1031 & $* * *$ & 0.0063 \\
\hline Comm Poverty Prog & 0.2747 & & 0.7708 & 2.3596 & $* * *$ & 0.5796 & 0.7779 & $* * *$ & 0.2631 \\
\hline Constant & -2.6655 & & 1.9923 & -5.9731 & $* * *$ & 1.4788 & -6.2765 & $* * *$ & 0.4830 \\
\hline Number of observation & 4,512 & & & 4,512 & & & 4,512 & & \\
\hline Rho & 0.3309 & & 0.0667 & 0.3275 & & 0.0403 & 0.2274 & & 0.03647 \\
\hline Wald test of rho $=0, \mathrm{chi}^{2}$ & 21.4 & $* * *$ & & 56.79 & $* * *$ & & 36.22 & $* * *$ & \\
\hline
\end{tabular}

Note: Robust standard errors are corrected for clustering at the communities' level. Number of hours for the sample, includes that report zero hours on each activity.

$* * * p<0.01, * * p<0.05, * p<0 . \mathrm{I}$

Source: Author's calculation from IFLS 5 (6 provinces on Java island).

\section{CONCLUSION}

This paper has found that the cash transfer programme for poor students significantly reduced the probability of working activities of children within households. The programme's impact is quite large. It was estimated to have reduced the probability of engagement in household chores, economic activities, and any activity by $32-38$ percentage points. In addition, the main robustness results show that the impact estimated varied among the children beneficiaries. The effects of the cash transfer for poor students programme seemed to favour boys over girls. The estimation analysis also showed that children from beneficiary households in urban areas experienced a smaller impact of the programme on participation in activities inside and outside the home than rural children. There will be I.I2-hour, 0.98-hour 
and 0.99-hour reductions in household chores, economic activities and any activity respectively when the average child receives a cash transfer programme. Finally, there will be a 2.57 -hour, 3.02-hour and I.96-hour reductions in household chores, economic activities and any activity respectively for children as beneficiaries. Thus, the findings of this paper suggest that the programme features in cash transfer for poor students can promote schooling and reduce the probability of child work.

The results in this paper also contributed to an ongoing discussion about the extent of the effects of cash transfer programme on child's work as a result of the income effects or the transfer conditions to poor households. Both the Indonesian and Latin American experiences showed poverty remains a core factor contributing to child work. The reduction in child work due to a cash transfer programme offer has the potential to break the intergenerational cycle of poverty, pushing many children living in vulnerable families out of child work and potentially pulling them into educational activities, such as schooling, that can benefit their overall future development of human capital and welfare (Edmonds \& Schady, 2012).

Cash transfer is a relatively safe policy instrument to improve child welfare. Over the past ten years, Indonesia has made major progress in reducing the number of children involved in child work. It has done so primarily by expanding education provision to increase the time children spend in school and reduce the time children allocate to work. This progress has been supported by the implementation of poverty alleviation programmes providing income support to vulnerable families. On the other hand, there are still many children at the primary and junior school levels who do not receive cash transfers as their financial support. These children are not registered at the basic education level. It could be because they are categorised as street children, helping their parents to earn money or their parents are not interested in sending their children to school because they live in remote areas.

Given the findings of this paper, policies are needed to ensure that the programme can effectively reach the poorest children who are out of school. Many students who have dropped out of school are not eligible to receive the programme, many of whom come from poor households who would need financial assistance. Thus, the programme should be expanded to benefit children who have dropped out of school.

\section{REFERENCES}

Alam, S. A. (2015). Parental health shocks, child labor and educational outcomes: Evidence from Tanzania. J Health Econ, 44, I6I-I75. doi:Io.Ior6/j.jhealeco.2015.09.004

Amarante, V., Ferrando, M., \& Vigorito, A. (20II). School Attendance, Child Labor and Cash Transfers. An Impact Evaluation of PANES. IDEAS Working Paper Series from RePEc.

Amin, S., Shakil Quayes, M., \& Rives, J. M. (2004). Poverty and Other Determinants of Child Labor in Bangladesh. Southern Economic Journal, 7o(4), 876-892.

Angrist, J. D. (200I). Estimation of Limited Dependent Variable Models With Dummy Endogenous Regressors: Simple Strategies for Empirical Practice. Journal of Business \& Economic Statistics, I9(I), 2-28. doi:Io.II98/o73500I0I5247257I

Attanasio, O., Mesnard, A., Fitzsimons, E., GutiéRrez, M. I., Gomez, A., \& Meghir, C. (2010). Children's schooling and work in the presence of a conditional cash transfer program in rural Colombia.Economic Development and Cultural Change, 58(2), I8I-2Io. doi:I0.Io86/648I88

Baez, J., \& Camacho, A. (20II). Assessing the Longterm Effects of Conditional Cash Transfers on Human Capital: Evidence from Colombia. IDEAS Working Paper Series from RePEc.

Baland, J. M., \& Robinson, J. A. (2000). Is Child Labor Inefficient? Journal of Political Economy, Io8(4), 663-679. doi:Io.Io86/3I6097

Bandara, A., Dehejia, R., \& Lavie-Rouse, S. (2015). The Impact of Income and Non-Income Shocks on Child Labor: Evidence from a Panel Survey of Tanzania. World Development, 67, 218-237. doi:Io.Ior6/j.worlddev.20I4.Io.or9

Bappenas. (2013). Poverty Reductions Programs in Indonesia. Jakarta, Indonesia: Bappenas.

Basu, K., Das, S., \& Dutta, B. (2010). Child labor and household wealth: Theory and empirical evidence of an inverted-U. Journal of Development Economics, 9I(I), 8-I4. doi:Io.roi6/j. jdeveco.2009.01.006 
Basu, K., \& Van, P. H. (I998). The Economics of Child Labor. The American Economic Review, 88(3), 4I2-427.

Beegle, K., Dehejia, R. H., \& Gatti, R. (2006). Child labor and agricultural shocks. Journal of Development Economics, 8I(I), 80-96. doi:Io.roI6/j. jdeveco.2005.05.003

BPS. (2015). Profil Penduduk Indonesia Hasil Supas 2015. Jakarta, Indonesia: BPS-Statistics Indonesia.

Cardoso, E., \& Souza, A. P. (2004). The impact of cash transfers on child labor and school attendance in Brazil (Vol. No. 04-Wo7): TN: Vanderbilt University.

de Janvry, A., Finan, F., Sadoulet, E., \& Vakis, R. (2006). Can conditional cash transfer programs serve as safety nets in keeping children at school and from working when exposed to shocks? Journal of Development Economics, 79(2), 349-373. doi:Io.IoI6/j.jdeveco.2006.oI.0I3

De Silva, I., \& Sumarto, S. (20I5). How do Educational Transfers Affect Child Labour Supply and Expenditures? Evidence from Indonesia of Impact and Flypaper Effects. Oxford Development Studies, 43(4), 483-507. doi:Io.1080/1360 0818.20I5.1032232

Deb, P., \& Rosati, F. (2002). Determinants of Child Labor and School Attendance: The Role of Household Unobservables. IDEAS Working Paper Series from RePEc.

Dehejia, Rajeev H., \& Gatti, R. (2005). Child Labor: The Role of Financial Development and Income Variability across Countries. Economic Development and Cultural Change, 53(4), 913-932. doi:I0.1086/4287I4

Del Carpio, X., Loayza, N., \& Wada, T. (2016). The Impact of Conditional Cash Transfers on the Amount and Type of Child Labor. World Development, 80, 33.

Edmonds, E. V., \& Schady, N. (20I2). Poverty Alleviation and Child Labor. American Economic Journal: Economic Policy, 4(4), I0O-I24. doi:Io.I257/pol.4.4.I00

Galiani, S., \& McEwan, P. J. (2013). The heterogeneous impact of conditional cash transfers. Journal of Public Economics, I03, 85-96. doi:Io.Ioi6/j. jpubeco.2013.04.004

Gee, K. A. (20I0). Reducing Child Labour Through Conditional Cash Transfers: Evidence from Nicaragua's Red de Protección Social. Development Policy Review, 28(6), 7II-732. doi:Io.IIII/j.I467-7679.2010.00506.x

Gitto, L., Santoro, D., \& Sobbrio, G. (2006). Choice of dialysis treatment and type of medical unit (private vs public): application of a recursive bivariate probit. Health Economics, I5(II), I25I-I256. doi:IO.IO02/hec.II39

Glewwe, P., \& Kassouf, A. L. (20I2). The impact of the Bolsa Escola/Familia conditional cash transfer program on enrollment, dropout rates and grade promotion in Brazil. The Journal of Development Economics, 97(2), 505. doi:Io.Ior6/j.jdeveco.20II.05.008

Glewwe, P., \& Olinto, P. (2004). Evaluating the impact of conditional cash transfers on schooling: An experimental analysis of Honduras' PRAF program. Unpublished manuscript, University of Minnesota.

Greene, W. H. (20I2). Econometric analysis (7th ed. ed.). Boston, MA: Prentice Hall.

Hoop, J. d., \& Rosati, F. C. (20I4). Cash Transfers and Child Labor. World Bank Research Observer, 29(2), 202-234. doi:Io.I093/wbro/lkuoo3

Latif, E. (2009). The impact of diabetes on employment in Canada. Health Economics, I8(5), 577-589. doi:I0.IO02/hec.I390

Macdonald, Z., \& Shields, M.A. (2004). Does problem drinking affect employment? Evidence from England. Health Economics, I3(2), I39-I55. doi:I0.1002/hec.8I6

Maluccio, J.A. (20I0). The Impact of Conditional Cash Transfers on Consumption and Investment in Nicaragua. Journal of Development Studies, 46(I), I4-38. doi:Io.1080/00220380903197952

Maluccio, J. A., \& Flores, R. (2005). Impact evaluation of a conditional cash transfer program: The Nicaraguan Red de Protección Social. Research Report. International Food Policy Research Institute. Washington DC.

Miller, C., \& Tsoka, M. (20I2). Cash Transfers and Children's Education and Labour among Malawi's Poor. Development Policy Review, 30(4), 499-522. doi:I0.IIII/j.I467-7679.20I2.00586.X

Ministry of Finance. (2016a). Implementation of Electronic Transfers in Indonesia Retrieved from

Ministry of Finance. (2016b). Nota Keuangan Beserta Anggaran Pendapatan dan Belanja Negara Tahun 20I6. Jakarta, Indonesia: Ministry of Finance.

Pais, P. S. M., Silva, F. d. F., \& Teixeira, E. C. (20I7). The influence of Bolsa Familia conditional cash transfer program on child labor in Brazil. International Journal of Social Economics, 44(2), 206-22I. doi:Io.IIo8/IJSE-02-2015-0038

Peruffo, M., \& Ferreira, P. C. (20I7). The Long-Term Effects of Conditional Cash Transfers on Child Labor and School Enrollment. Economic Inquiry, 55(4), 2008-2030. doi:Io.IIII/ ecin.I2457 
Ravallion, M., \& Wodon, Q. (2000). Does Child Labour Displace Schooling? Evidence on Behavioural Responses to an Enrollment Subsidy. The Economic Journal: the Quarterly Journal of the Royal Economic Society, IIO, C.

Rosati, F. C. (2003). Children's Working Hours and School Enrollment: Evidence from Pakistan and Nicaragua. The World Bank Economic Review, $I 7(2)$, 283-295. doi:Io.Io93/wber/lhgo23

Sim, A., Suryadarma, D., \& Suryahadi, A. (2017). The Consequences of Child Market Work on the Growth of Human Capital. World Development, 9I, I44-I55. doi:I0.IOI6/j.worlddev.2016.11.007

Skoufias, E., \& Parker, S. W. (20oI). The Impact of Progresa on Work, Leisure and Time Allocation : Final Report. Retrieved from Washington, DC:

Suryahadi, A., Priyambada, A., \& Sumarto, S. (2005). Poverty, School and Work: Children during the Economic Crisis in Indonesia. Development \& Change, 36(2), 35I-373. doi:I0.IIII/j.00I2-I55X.2005.004I4.X
Tabatabai, H. (2009). Conditional Cash Transfers and Child Labour (Vol. 9, pp. I79-I82).

Webbink, E., Smits, J., \& de Jong, E. (2013). Household and context determinants of child labor in 22I districts of 18 developing countries. Social Indicators Research, IIO(2), 8I9-836.

Wooldridge, J. M. (2010). Econometric analysis of cross section and panel data (2nd ed. ed.). Cambridge, Mass.: MIT Press.

World Bank. (20I2a). Protecting Poor and Vulnerable Households in Indonesia. Jakarta, Indonesia: World Bank.

World Bank. (2012b). Social Assistance Program and Public Expenditure Review 5 : Cash Transfer for Poor Students Jakarta, Indonesia: World Bank.

Zapata, D., Contreras, D., \& Kruger, D. (20II). Child Labor and Schooling in Bolivia: Who's Falling Behind? The Roles of Domestic Work, Gender, and Ethnicity. World Development, 39(4), 588-599. doi:Io.IoI6/j.worlddev.2010.08.022 
